\title{
Analisis Nilai Karakter Peduli Sosial Melalui Metode Role Playing di Kelas V SDI Miftahul Huda Plosokandang Kabupaten Tulungagung
}

\author{
Nik Haryanti $^{*}$, Nurul Syalafiyah ${ }^{2}$, Budi Harianto ${ }^{3}$, Sony Eko Adisaputro ${ }^{4}$ \\ ${ }^{1,2,4}$ IAI Pangeran Diponegoro Nganjuk, Indonesia \\ ${ }^{3}$ UIN Sayyid Ali Rahmatullah, Indonesia \\ *email: nikharyanti1983@gmail.com
}

\begin{abstract}
The purpose of this study was to determine the value of the social care character of students during or after learning with the role-playing method and to describe learning using the role-playing method that develops the character of social care. This research method is qualitative research. Data collection techniques used are questionnaires, observations, interviews, and documentation. The data analysis techniques used are: 1) data reduction 2) data presentation and 3) conclusion drawing/verification. The results of the research show that 1) The value of social care characters through the role-playing method in the learning process in Class V SDI Miftahul Huda Plosokandang, Tulungagung Regency is known based on the value of the social care character of students when participating in learning with the role-playing method, it can be seen that the average value of the questionnaire is 4.121 with a percentage of 82.42 or categorized as good. Meanwhile, the values of the social care character of students after participating in learning using the role-playing method in which the questionnaire was filled out by friends of the students were seen as an average of 4.125 with a percentage of 82.5 or in the good category. 2) Learning with the roleplaying method that develops the social care character of the fifth-grade students of SDI Miftahul Huda Plosokandang, Tulungagung Regency, is carried out in 3 meetings. Based on the results of observations of learning activities obtained from the average or percentage obtained at the first meeting, which is $70.90 \%$ in the predicate or sufficient category. While the second meeting is $80.00 \%$ in the predicate or good category. Furthermore, the third meeting is $94.54 \%$ in the predicate or category of very good.
\end{abstract}

Keywords: Social Care Character, Role Playing Method

\begin{abstract}
Abstrak: Tujuan penelitian ini adalah untuk mengetahui nilai karakter peduli sosial siswa-siswa saat atau setelah pembelajaran dengan metode role playing dan mendeskripsikan pembelajaran dengan metode role playing yang mengembangkan karakter peduli sosial. Metode penelitian ini merupakan suatu penelitian kualitatif. Teknik pengumpulan data yang digunakan adalah angket, observasi, wawancara, dan dokumentasi. Teknik analisis data yang digunakan adalah yaitu: 1) reduksi data 2) penyajian data dan 3) penarikan kesimpulan/verifikasi. Hasil penelitiannya menunjukkan bahwa 1) Nilai karakter peduli sosial melalui metode role playing dalam proses pembelajaran di Kelas V SDI Miftahul Huda Plosokandang Kabupaten Tulungagung diketahui berdasarkan nilai karakter peduli sosial siswa saat mengikuti pembelajaran dengan metode role playing dapat dilihat nilai rata-rata dari angket tersebut sebesar 4,121 dengan persentase 82,42 atau dikategorikan baik. Sedangkan nilai-nilai karakter peduli sosial siswa setelah mengikuti pembelajaran dengan metode role playing yang mana angket diisi oleh teman dari siswa dilihat rata-rata sebesar 4,125 dengan persentase 82,5 atau dalam kategori Baik. 2) Pembelajaran dengan metode role playing
\end{abstract}


yang mengembangkan karakter peduli sosial siswa-siswa Kelas V SDI Miftahul Huda Plosokandang Kabupaten Tulungagung dilakukan dengan 3 pertemuan. Berdasarkan hasil observasi kegiatan pembelajaran diperoleh dari rata-rata atau prosentase yang diperoleh pada pertemuan I yaitu $70,90 \%$ dalam predikat atau kategori cukup. Sedangkan pertemuan II yaitu $80 \%$ dalam predikat atau kategori Baik. Selanjutnya pertemuan III yaitu yaitu 94,54\% dalam predikat atau kategori Sangat Baik.

Kata kunci: Karakter Peduli Sosial, Metode Role Playing

Copyright (c) 2021 The Authors. This is an open access article under the CC BY-SA 4.0 license (https://creativecommons.org/licenses/by-sa/4.0/)

\section{PENDAHULUAN}

Pendidikan karakter menjadi pondasi yang utama untuk mensukseskan Indonesia Emas 2045. Pendidikan karakter merupakan bagian dari proses membentuk kepribadian bangsa. Kementrian Pendidikan Nasional menjadikan pendidikan karakter sebagai fokus pendidikan diseluruh nusantara (Herdani, 2010:56). Pendidikan karakter menjadi suatu hal yang sangat penting untuk diterapkan dan perlu mendapatkan perhatian untuk meningkatkan kualitas bangsa.

Mengingat pada zaman yang semakin maju ini banyak ditemui sikap dan perilaku manusia yang cenderung kurang peduli terhadap lingkungan sekitar. Sebagai lingkungan pendidikan yang paling utama keluarga khususnya harus dapat menjadi contoh yang baik. Keluarga mempunyai peran dalam membentuk watak dan sikap anak. Sekolah dasar sebagai lembaga pendidikan dasar mempunyai tugas untuk mencetak generasi yang berakhlak mulia melalui pendidikan karakter pada siswanya. Dengan demikian, pendidikan karakter dapat dilakukan baik di rumah, di sekolah maupun di masyarakat.

Pendidikan karakter dalam Kurikulum 2013 mempunyai target membentuk manusia yang kreatif, inovatif dan terampil, serta memiliki pengetahuan yang terintegrasi. Pelaksanaan Kurikulum 2013 merupakan aktualisasi kurikulum dalam pembelajaran dan pembentukan kompetensi serta karakter peserta didik. Dengan demikian dalam pembentukan karakter peserta didik, guru harus aktif untuk menciptakan suasana pembelajaran yang sesuai dengan perencanaan yang telah diprogramkan.

Menurut Samani dan Hariyanto (2012:2) pendidikan karakter semakin hari semakin mendapat pengakuan dari masyarakat Indonesia saat ini. Pendidikan karakter sangat dibutuhkan pada segala jenjang pendidikan, mulai dari pendidikan dasar, pendidikan menengah pertama sampai dengan perguruan tinggi. Bahkan, 
pendidikan karakter dimulai semenjak usia dini, sehingga ketika dalam usia dewasa, individu menjadi kebal terhadap tantangan dan rintangan yang datang untuk menggoda keyakinannya yang pada akhirnya permasalahan yang ada di dunia pendidikan segera mendapatkan penyelesaian.

Sekolah dasar sebagai suatu lembaga pendidikan yang memiliki tugas membentuk nilai karakter kepada siswa. Nilai kepedulian sosial menjadi salah satu nilai yang perlu untuk ditanamkan pada diri siswa. Adanya proses penanaman nilai peduli sosial bagi guru di sekolah sangatlah dianjurkan, mengingat telah pudarnya rasa empati yang dapat dilihat adanya sikap acuh dengan kondisi teman, meningkatnya perkelahian antar-siswa dan lain sebagainya.

Menurut Listyarti (2012: 7), peduli sosial merupakan suatu tindakan atau sikap untuk membantu orang lain yang memerlukan bantuan. Yaumi (2014: 77) menjelaskan bahwa kepedulian sosial ialah suatu bentuk kesadaran manusia sebagai makhluk sosial yang tidak memungkinkan untuk hidup sendirian. Dengan demikian, peduli sosial ialah suatu tindakan yang dilakukan dengan sengaja kepada orang lain yang membutuhkan.

Setiap individu pada dasarnya memiliki karakter masing-masing. Salah satu karakter anak yang harus dibentuk dan dikembangkan dalam dunia pendidikan adalah sikap kepedulian sosial terhadap sesama teman sebaya. Membentuk sikap kepedulian sosial sesama di lingkungan sekolah, menjadi suatu hal yang bisa dibilang sulit untuk diterapkandan harus ditanam sejak dini. Hal ini dapat dilihat dari perkembangan globalisasi, dimana semakin pesatnya kemajuan teknologi yang berdampak pada lunturnya sikap peduli individu terhadap orang lain. Individu mulai asik dengan dirinya sendiri dan tidak memperhatikan orang lain.

Kepedulian sosial sesama teman sebaya bisa dilakukan dengan cara saling tolong-menolong, berempati, berbagi, bekerjasama, menghormati, sopan santun, tanggungjawab sosial dan dukungan sosial. Kurangnya sikap kepedulian sosial jika dibiarkan akan menghambat perkembangan sosial dan interaksi sosial siswa dalam bergaul dilingkungan sekolah, sehingga siswa pada akhirnya menjadi lebih cenderung memikirkan dirinya sendiri. Dalam rangka memberi bantuan untuk mengembangkan kepedulian sosial dapat dilakukan melalui metode role playing. 
Hasil survai pada saat pra-observasi yang dilakukan di kelas V SDI Miftahul Huda menunjukkan ada hambatan-hambatan dari guru yaitu siswa kurang memiliki rasa empati dan komunikasi yang baik dalam proses pembelajaran di kelas. Mengingat pentingnya penanaman karakter peduli sosial diperlukan adanya suatu metode pembelajaran yang digunakan oleh guru. Metode pembelajaran role playing diyakini dapat membuat siswa memahami dan mempunyai penghayatan terhadap isi materi yang diberikan oleh guru. Penerapan role playing sasarannya untuk menanamkan kedisiplinan, kemampuan berkomunikasi, serta menumbuhkan mempunyai nilai kepedulian sosial yang baik pada siswa.

Kegiatan pembelajaran yang menyenangkan di kelas sangat dibutuhkan oleh siswa. Dengan metode role playing, siswa banyak belajar tentang berbagai peran terkait kepedulian sosial. Penguatan karakter peduli sosial melalui metode role playing ditujukan untuk membentuk jiwa kedermawanan dan rasa kepedulian sosial yang tinggi agar dapat diterapkan dan ditanamkan dalam kehidupan keseharian siswa.

Role playing disebut juga dengan sosiodrama sebagai suatu metode pembelajaran yang dapat memotivasi siswa untuk bermain peran terkait dengan materi pembelajaran yang diajarkan guru. Role playing sebagai suatu model pembelajaran bertujuan untuk membantu siswa menemukan jati diri di dunia sosial dan memecahkan dilema dengan bantuan kelompok (Hamzah, 2009). Role playing merupakan suatu metode yang lebih banyak interaksi siswa baik dengan siswa lainnya atau dengan situasi sosial yang ada di lingkungan sekitar. Siswa bertindak memerankan tokoh yang sesuai menjadi lakonnya. Siswa berinteraksi untuk memerankan peran secara terbuka. Dalam pelaksanaan metode ini seorang guru dituntut untuk mencermati apa yang perlu dibenahi dari perilaku yang diperankan oleh siswa (Yamin, 2012).

Setiap metode pembelajaran mempunyai kelemahan dan kelebihan. Demikian halnya dengan metode role playing. Setiap metode pembelajaran bersifat saling melengkapi. Penerapan metode role playing dapat diterapkan pada materi pelajaran yang lain, tergantung pada karakteristik materi pelajaran yang diberikan. Dengan pembelajaran role playing siswa menjadi lebih aktif untuk memainkan peran sesuai 
dengan peran yang telah ditentukan, sehingga nilai-nilai karakter peduli sosial yang ditanamkan pada siswa dapat membawa perubahan yang lebih baik.

\section{METODE}

Penelitian ini merupakan suatu penelitian kualitatif, karena penelitian ini bertujuan untuk mendeskripsikan karakter peduli sosial dan proses pembelajarannya. Penentuan subjek dalam penelitian ini berdasarkan pertimbangan sebagai berikut: (1) Kepala sekolah dianggap sebagai pihak yang paling mengetahui situasi dan kondisi terkait apa yang ada di sekolah, (2) Guru kelas karena guru tersebut paling sering terlibat langsung dengan pendidikan anak di kelas, (3) petugas sekolah karena sering berinteraksi dengan siswa. (4) Siswa Kelas V SDI Miftahul Huda Plosokandang Kabupaten Tulungagung karena materi pembelajaran tentang nilai peduli sosial ada di Kelas V.

Instrumen penelitian dan teknik pengumpulan data yang digunakan dalam penelitian ini adalah menggunakan dokumentasi, lembar observasi, angket dan wawancara. Analisis data penelitian kualitatif menurut Sugiono (2010: 338) dapat dilakukan melalui tiga alur kegiatan yang terjadi secara bersamaan yaitu: 1) reduksi data (data reduction), 2) penyajian data (data display) dan 3) penarikan kesimpulan/verifikasi (conclusion drawing/veriffication).

\section{HASIL DAN PEMBAHASAN}

\section{Hasil}

1. Nilai-nilai karakter peduli sosial siswa saat atau setelah mengikuti pembelajaran dengan metode role playing

Nilai-nilai karakter peduli sosial siswa saat mengikuti pembelajaran dengan metode role playing dapat dilihat dari hasil angket yang diisi oleh siswa, angket dari nilai-nilai karakter peduli sosial siswa di rata-rata dari setiap indikator yaitu memperlakukan orang lain dengan sopan, bertindak santun, toleransi terhadap perbedaan, tidak suka menyakiti orang lain, tidak mengambil keuntungan dari orang lain, mampu bekerja sama, menyayangi manusia dan makhluk lain dan cinta damai dalam menghadapi persoalan disajikan dalam tabel sebagai berikut:

Tabel 1. Hasil analisis nilai karakter peduli sosial siswa 


\begin{tabular}{llccc}
\hline No & Indikator & $\begin{array}{c}\text { Rata- } \\
\text { rata }\end{array}$ & $\begin{array}{c}\text { Persenta } \\
\text { se }\end{array}$ & Keterangan \\
& & & & \\
\hline 1 & Memperlakukan orang lain dengan sopan & 3,78 & 75,6 & Baik \\
\hline 2 & Bertindak santun & 3,96 & 79,2 & Baik \\
\hline 3 & Toleran terhadap perbedaan & 4,01 & 80,2 & Baik \\
\hline 4 & Tidak suka menyakiti orang lain & 4,37 & 87,4 & Sangat Baik \\
\hline 5 & Tidak mengambil keuntungan dari orang & 4,212 & 84,24 & Sangat Baik \\
& lain & 4,24 & 84,8 & Sangat Baik \\
\hline 6 & Mampu bekerja sama & 4,06 & 81,2 & Baik \\
\hline 7 & Menyayangi manusia dan makhluk lain & 4,338 & 86,76 & Sangat Baik \\
\hline 8 & Cinta damai dalam menghadapi persoalan & 4,121 & 82,42 & Baik \\
\hline \multicolumn{2}{c}{ Rata-rata } & & &
\end{tabular}

Sumber Data: Olahan Peneliti (2019)

Berdasarkan tabel di atas jika dilihat dari nilai rata-rata dari angket tersebut sebesar 4,121 dengan persentase 82,42 atau nilai-nilai karakter peduli sosial dari siswa dapat dikategorikan baik, artinya nilai-nilai karakter peduli sosial dapat dikategorikan baik. Secara rinci diuraikan sebagai berikut:

1. Memperlakukan orang lain dengan sopan mendapatkan skor rata-rata 3,78 dengan persentase 75,6 dalam kategori baik. Hal ini dikarenakan siswa dalam pergaulan sehari-hari memiliki perilaku yang lemah lembut, sopan, mengucapkan salam ketika masuk kelas dan bertegur sapa dengan teman.

2. Bertindak santun mendapatkan skor rata-rata 3,96 dengan persentase 79,2 dalam kategori baik. Hal ini dikarenakan dalam rutinitas sehari-hari siswa berbicara santun, mengajak berjabat tangan, menyapa dan tersenyum saat bertemu dengan orang lain.

3. Toleransi terhadap perbedaan mendapatkan skor rata-rata 4,01 dengan persentase 80,2 dalam kategori baik. Hal ini dikarenakan dalam rutinitas sehari-hari siswa menghargai orang lain dengan tidak memaksakan kehendaknya.

4. Tidak suka menyakiti orang lain mendapatkan skor rata-rata 4,37 dengan persentase 87,4 dalam kategori sangat baik. Hal ini dikarenakan siswa dalam pergaulan sehari-hari senantiasa saling mengasihi.

5. Tidak mengambil keuntungan dari orang lain mendapatkan skor rata-rata 4,212 dengan persentase 84,24 dalam kategori sangat baik. Hal ini 
dikarenakan siswa dalam pergaulan sehari-hari tidak suka membicarakan keburukan orang lain dan saling menyembunyikan kelemahan masingmasing.

6. Mampu bekerja sama mendapatkan skor rata-rata 4,24 dengan persentase 84,8 dalam kategori sangat baik. Hal ini dikarenakan siswa dalam pergaulan sehari-hari senantiasa mau membantu dan dalam suasana penuh kebersamaan.

7. Menyayangi manusia dan makhluk lain mendapatkan skor rata-rata 4,06 dengan persentase 81,2 dalam kategori baik. Hal ini dikarenakan siswa mempunyai kasih sayang dan tercipta saling mempercayai.

8. Cinta damai dalam menghadapi persoalan mendapatkan skor rata-rata 4,338 dengan persentase 86,76 dalam kategori sangat baik. Hal ini dikarenakan siswa dalam pergaulan sehari-hari senantiasa menggunakan tata bahasa yang baik dan terbiasa dengan suasana yang riang gembira.

Hal ini mencerminkan bahwa nilai-nilai karakter peduli sosial siswa saat mengikuti pembelajaran dengan metode role playing Kelas V SDI Miftahul Huda Plosokandang Kabupaten Tulungagung kategori Baik. Dengan demikian siswa dalam pergaulan sehari-hari memiliki perilaku yang lemah lembut, sopan, mengucapkan salam ketika masuk kelas dan bertegur sapa dengan teman, berbicara santun, mengajak berjabat tangan, menyapa dan tersenyum saat bertemu dengan orang lain, menghargai orang lain dengan tidak memaksakan kehendaknya, sehingga tercipta lingkungan yang mempunyai kepedulian sosial yang baik.

Sedangkan nilai-nilai karakter peduli sosial siswa setelah mengikuti pembelajaran dengan metode role playing yang mana angket diisi oleh teman dari siswa untuk mengetahui nilai-nilai karakter peduli sosial temannya dengan indikator yaitu memperlakukan orang lain dengan sopan, bertindak santun, toleransi terhadap perbedaan, tidak suka menyakiti orang lain, tidak mengambil keuntungan dari orang lain, mampu bekerja sama, menyayangi manusia dan makhluk lain dan cinta damai dalam menghadapi persoalan disajikan dalam tabel sebagai berikut:

Tabel 2. Hasil analisis nilai karakter peduli sosial teman siswa 


\begin{tabular}{llccc}
\hline No & \multicolumn{1}{c}{ Indikator } & $\begin{array}{c}\text { Rata- } \\
\text { rata }\end{array}$ & $\begin{array}{c}\text { Persen } \\
\text { tase }\end{array}$ & Keterangan \\
\hline 1 & $\begin{array}{l}\text { Memperlakukan orang lain dengan } \\
\text { sopan }\end{array}$ & 3,79 & 75,8 & Baik \\
\hline 2 & Bertindak santun & 3,94 & 78,8 & Baik \\
\hline 3 & Toleran terhadap perbedaan & 4,15 & 83 & Baik \\
\hline 4 & Tidak suka menyakiti orang lain & 4,25 & 85 & Sangat Baik \\
\hline 5 & $\begin{array}{l}\text { Tidak mengambil keuntungan dari } \\
\text { orang lain }\end{array}$ & 4,35 & 87 & Sangat Baik \\
\hline 6 & Mampu bekerja sama & 4,11 & 82,2 & Baik \\
\hline 7 & Menyayangi manusia dan makhluk lain & 4,24 & 84,8 & Sangat Baik \\
\hline 8 & $\begin{array}{l}\text { Cinta damai dalam menghadapi } \\
\text { persoalan }\end{array}$ & 4,17 & 83,4 & Baik \\
\hline & $\quad$ Rata-rata & 4,125 & 82,5 & Baik \\
\hline
\end{tabular}

Sumber Data: Olahan Peneliti (2019)

Berdasarkan tabel di atas jika dilihat dari nilai rata-rata nilai karakter peduli sosial teman siswa ini mendapatkan rata-rata sebesar 4,125 dengan persentase 82,5 atau dalam kategori baik. Artinya nilai-nilai karakter peduli sosial dapat dikategorikan baik. Secara rinci diuraikan sebagai berikut:

1. Memperlakukan orang lain dengan sopan mendapatkan skor rata-rata 3,79 dengan persentase 75,8 dalam kategori baik. Hal ini dikarenakan siswa dengan temannya bisa berbicara lemah lembut, sopan, salam dan sapa dengan temannya.

2. Bertindak santun mendapatkan skor rata-rata 3,94 dengan persentase 78,8 dalam kategori baik. Hal ini dikarenakan dalam rutinitas sehari-hari siswa dengan temannya berbicara santun, menyapa dan tersenyum saat bertemu dengan orang lain.

3. Toleransi terhadap perbedaan mendapatkan skor rata-rata 4,15 dengan persentase 83 dalam kategori baik. Hal ini dikarenakan dalam rutinitas sehari-hari siswa dengan temannya saling menghargai dengan tidak memaksakan kehendaknya.

4. Tidak suka menyakiti orang lain mendapatkan skor rata-rata 4,25 dengan persentase 85 dalam kategori sangat baik. Hal ini dikarenakan siswa dalam pergaulan sehari-hari siswa dengan temannya senantiasa saling mengasihi. 
5. Tidak mengambil keuntungan dari orang lain mendapatkan skor rata-rata 4,35 dengan persentase 87 dalam kategori sangat baik. Hal ini dikarenakan siswa dengan temannya tidak suka membicarakan keburukan dan saling menyembunyikan kelemahan masing-masing.

6. Mampu bekerja sama mendapatkan skor rata-rata 4,11 dengan persentase 82,2 dalam kategori baik. Hal ini dikarenakan siswa dengan temannya senantiasa mau membantu dan dalam suasana penuh kebersamaan.

7. Menyayangi manusia dan makhluk lain mendapatkan skor rata-rata 4,24 dengan persentase 84,8 dalam kategori sangat baik. Hal ini dikarenakan siswa dengan temannya mempunyai kasih sayang dan tercipta saling mempercayai.

8. Cinta damai dalam menghadapi persoalan mendapatkan skor rata-rata 4,17 dengan persentase 83,4 dalam kategori baik. Hal ini dikarenakan siswa dengan temannya senantiasa menggunakan tata bahasa yang baik dan terbiasa dengan suasana yang riang gembira.

Jadi berdasarkan analisis di atas nilai-nilai karakter peduli sosial siswa saat mengikuti pembelajaran dengan metode role playing dapat dilihat nilai rata-rata dari angket tersebut sebesar 4,121 dengan persentase 82,42 atau nilai-nilai karakter peduli sosial dari siswa dapat dikategorikan baik, artinya nilai-nilai karakter peduli sosial dapat dikategorikan baik. Sedangkan nilai-nilai karakter peduli sosial siswa setelah mengikuti pembelajaran dengan metode role playing yang mana angket diisi oleh teman dari siswa dilihat rata-rata sebesar 4,125 dengan persentase 82,5 atau dalam kategori Baik. Artinya nilai-nilai karakter peduli sosial dapat dikategorikan baik.

2. Pembelajaran dengan metode role playing yang mengembangkan karakter peduli sosial siswa-siswa Kelas V SDI Miftahul Huda Plosokandang Kabupaten Tulungagung

Pembelajaran dengan metode role playing yang mengembangkan karakter peduli sosial siswa-siswa Kelas V SDI Miftahul Huda Plosokandang Kabupaten Tulungagung yang pelaksanaannya dilaksanakan 3 Pertemuan yang dilakukan sebagai berikut:

a. Pertemuan Pertama 
1) Persiapan

Persiapan pembelajaran dengan metode role playing yang pertama dilakukan oleh guru adalah melakukan persiapan. Berdasarkan wawancara dengan kepala sekolah mengenai persiapan yang dilakukan dalam metode role playing dalam pembelajaran nilai-nilai karakter peduli sosial yaitu guru dan siswa mempersiapkan dialog bermain peran yang akan diperagakan di depan kelas sebagaimana hasil wawancara dengan kepala sekolah yang menyatakan bahwa: "Kepala sekolah mengetahui persiapan yang dilakukan dalam metode role playing dalam pembelajaran nilai-nilai karakter peduli sosial yaitu guru dan siswa mempersiapkan dialog bermain peran yang akan diperagakan di depan kelas". (Wawancara: Kusmani, 2/4/2019).

Berdasarkan wawancara dengan guru mengenai persiapan yang dilakukan dalam metode role playing dalam pembelajaran nilai-nilai karakter peduli sosial, menyatakan bahwa: "Persiapan yang dilakukan dengan menentukan topik yang dimainkan, memberikan gambaran tentang peran yang akan dimainkan, memilih siswa sesuai dengan perannya untuk memainkan peran sesuai dengan naskah yang dipersiapkan sebelumnya dan memberitahukan peran yang akan dimainkan oleh masing-masing siswa. Dialog bermain peran sudah dipersiapkan, siswa tinggal menghafalnya dirumah, karena persiapan sudah dilakukan sebelum pembelajaran berlangsung, guru memberikan pengarahan terkait permainan. Dalam pertemuan pertama ini siswa belum begitu terbiasa dengan kegiatan pembelajaran bermain peran". (Wawancara: Tuminah, 2/4/2019).

Data tersebut didukung dengan wawancara yang menyatakan bahwa: "Sebelum kegiatan pembelajaran bermain peran dilaksanakan ada beberapa hal yang harus dipersiapkan mulai dari penentuan topik, menggambarkan peran yang akan dimainkan, membagian peran dalam permainan dan persiapan naskah. Tahap persiapan ini harus dipersiapkan dengan matang, agar pelaksanaannya nanti tidak mengecewakan”. (Wawancara: Sholeh Ridlo, 2/4/ 2019). 
Berdasarkan wawancara dengan siswa mengenai persiapan yang dilakukan dalam metode role playing dalam pembelajaran nilai-nilai karakter peduli sosial menyatakan bahwa: "Saya dikasih teks dialog permainan peran yang harus dihafalkan di rumah, sehingga sewaktu di sekolah tinggal mempertontonkannya di depan kelas. Namun dalam pertemuan pertama ini saya belum begitu paham dalam pelaksanaannya, namun saya senang". (Wawancara: Iqbal Ashar Handika, 4/4/2019). Hal senada juga diungkapkan oleh siswa yang menyatakan bahwa: "Saya diberi oleh ibu guru teks dialog yang harus saya hapalkan dulu dirumah untuk bermain peran di kelas minggu depan. Pertemuan pertama ini saya harus menghafal dan bisa berperan nantinya". (Wawancara: Safira, 4/4/2019)

Dari hasil wawancara tersebut dapat diketahui kepala sekolah, guru kelas dan siswa mengungkapkan bahwa persiapan yang dilakukan dalam metode role playing dalam pembelajaran nilai-nilai karakter peduli sosial yaitu guru dan siswa mempersiapkan dialog bermain peran yang akan diperagakan di depan kelas.

2) Tindakan dramatik dan diskusi

Tindakan dramatik dan diskusi ini dalam pelaksanaannya siswa memerankan tokoh-tokoh sesuai dengan bagiannya masing-masing dengan dampingan guru gelas. Berdasarkan wawancara dengan kepala sekolah mengetahui mengenai tindakan dramatik dan diskusi yang diberikan dalam metode role playing dalam pembelajaran nilai-nilai karakter peduli sosial, hal itu dilakukan untuk mendemonstrasikan peran yang sedang dimainkan oleh siswa sebagaimana hasil wawancara dengan kepala sekolah yang menyatakan bahwa: "Kepala sekolah mengetahui tindakan dramatik dan diskusi yang diberikan dalam metode role playing dalam pembelajaran nilai-nilai karakter peduli sosial, hal itu dilakukan untuk mendemonstrasikan peran yang sedang dimainkan oleh siswa. Kegiatan pembelajaran ya diawal siswa harus terbiasa dulu, nanti pasti lama-lama akan terbiasa juga”. (Wawancara: Kusmani, 4/4/2019). 
Berdasarkan wawancara dengan guru mengenai tindakan dramatik dan diskusi yang diberikan dalam metode role playing dalam pembelajaran nilai-nilai karakter peduli sosial menyatakan bahwa: "Pelaksanaan bermain dilakukan sesuai rencana yaitu pemain peran memainkan peran sesuai peran yang diberikan kepadanya. Setelah permainan selesai, seluruh siswa berpartisipasi untuk diskusi terkait suasana permainan peran. Siswa bermain drama dengan bergantian secara berkelompok (elaborasi) sesuai dengan peran yang dimainkan. Kegiatan pembelajaran di awal menyenangkan, tapi siswa harus terbiasa dulu, nanti juga akan lebih paham dengan karakternya masing-masing”. (Wawancara: Tuminah, 4/4/ 2019). Data tersebut didukung dengan wawancara yang menyatakan bahwa: "Pelaksanaan bermain peran dilaksanakan sesuai dengan perencanaan yang telah dibuat pada tahap persiapan, siswa mulai memainkan peran dan pastinya terlihat menyenangkan, namun masih ada beberapa siswa yang belum sesuai harapan". (Wawancara: Sholeh Ridlo, 2/4/2019).

Berdasarkan wawancara dengan siswa mengenai tindakan dramatik dan diskusi yang diberikan dalam metode role playing dalam pembelajaran nilai-nilai karakter peduli sosial menyatakan bahwa: "Saya dan teman satu tim mendemonstrasikan peran yang telah dipersiapkan sebelumnya. Kegiatan ini sangat menyenangkan dan membuat saya lebih ingin banyak membantu jika ada yang membutuhkan”. (Wawancara: Iqbal Ashar Handika, 29/3/2019). Hal senada juga diungkapkan oleh siswa yang menyatakan bahwa: "Saya sangat senang dalam bermain peran, karena dapat menjiwai peran tersebut dan menggugah hati saya untuk lebih peduli terhadap lingkungan saya”. (Wawancara: Safira, 29/3/2019).

Dari hasil wawancara tersebut dapat diketahui kepala sekolah, guru kelas dan siswa mengungkapkan bahwa tindakan dramatik dan diskusi yang diberikan dalam metode role playing dalam pembelajaran nilai-nilai karakter peduli sosial, hal itu dilakukan untuk mendemonstrasikan peran yang sedang dimainkan oleh siswa. 
3) Evaluasi bermain peran

Evaluasi bermain peran dilakukan untuk memberikan penilaian dan memberikan keputusan berhasilnya kegiatan permainan peran. Berdasarkan wawancara dengan kepala sekolah mengetahui mengenai evaluasi bermain peran yang diberikan dalam metode role playing dalam pembelajaran nilai-nilai karakter peduli sosial dengan melihat keseriusan siswa dalam berakting dan semangat belajarnya menjadi lebih baik serta yang terpenting siswa lebih peduli dengan lingkungan sekitar sebagaimana hasil wawancara dengan kepala sekolah yang menyatakan bahwa: "Kepala sekolah mengetahui evaluasi bermain peran yang diberikan dalam metode role playing dalam pembelajaran nilai-nilai karakter peduli sosial dengan melihat keseriusan siswa dalam berakting dan semangat belajarnya menjadi lebih baik serta yang terpenting siswa lebih peduli dengan lingkungan sekitar. Dalam pelaksanaan pembelajaran pertemuan pertama masih kurang baik, siswa belum begitu menguasai perannya". (Wawancara: Kusmani, 8/4/2019).

Berdasarkan wawancara dengan guru mengenai evaluasi bermain peran yang diberikan dalam metode role playing dalam pembelajaran nilai-nilai karakter peduli sosial, menyatakan bahwa: "Setelah melakukan kegiatan role playing, masing-masing kelompok diberi pertanyaan oleh guru. Untuk mengetahui sekilas mengenai pemahaman siswa terkait materi pelajaran yang telah diajarkan pada siswa. Setelah itu guru memberikan penilaian dan memberikan keputusan berhasilnya kegiatan permainan peran yang telah berlangsung. Pembelajaran dengan metode role playing membutuhkan pembiasaan, masih ada siswa yang belum menguasai karakter perannya". (Wawancara: Tuminah, 8/4/2019).

Data tersebut didukung dengan wawancara yang menyatakan bahwa: "Setelah diadakan pelaksanaan bermain peran ada penilaian yang dilakukan oleh guru, yang mana guru memberikan arahan dan perbaikan yang harus dilakukan oleh siswa. Jika sudah sesuai dengan 
harapan, guru memberikan penghargaan melalui ucapan”. (Wawancara: Sholeh Ridlo, 8/4/2019). Berdasarkan wawancara dengan siswa mengenai evaluasi bermain peran yang diberikan dengan metode role playing dalam pembelajaran nilai-nilai karakter peduli sosial, menyatakan bahwa: "Setelah bermain peran, teman-teman pengamat diberi pertanyaan oleh ibu guru". (Wawancara: Iqbal Ashar Handika, 8/4/2019). Hal ini senada juga diungkapkan oleh siswa yang menyatakan bahwa: "Teman-teman yang menjadi pengamat diberi pertanyaan yang berkaitan dengan keberhasilan saya dan teman-teman dalam bermain peran”. (Wawancara: Safira, 8/4/2019)

Dari hasil wawancara tersebut dapat diketahui kepala sekolah, dan guru kelas mengungkapkan bahwa evaluasi bermain peran yang diberikan dalam metode role playing dalam pembelajaran nilai-nilai karakter peduli sosial dengan melihat keseriusan siswa dalam berakting dan semangat belajarnya menjadi lebih baik serta yang terpenting siswa lebih peduli dengan lingkungan sekitar.

Pembelajaran dengan metode role playing yang mengembangkan karakter peduli sosial siswa-siswa Kelas V SDI Miftahul Huda Plosokandang Kabupaten Tulungagung dapat berdasarkan hasil observasi kegiatan pembelajaran. Data hasil observasi kegiatan pembelajaran disajikan dalam tabel sebagai berikut:

Tabel 3. Observasi Kegiatan Pembelajaran 1

\begin{tabular}{clc}
\hline No & \multicolumn{1}{c}{ Aspek yang diobservasi } & Pertemuan I \\
\hline 1. & $\begin{array}{l}\text { Cara penyampaian dan penjelasan guru tentang } \\
\text { pembelajaran role playing dapat diterima oleh siswa }\end{array}$ & 3 \\
\hline 2. & $\begin{array}{l}\text { Penggunaan alat peraga digunakan guru dengan baik dalam } \\
\text { pembelajaran }\end{array}$ & 3 \\
\hline 3. & $\begin{array}{l}\text { Guru dapat mengajak siswa untuk aktif mengikuti } \\
\text { pembelajaran role playing }\end{array}$ & 4 \\
\hline 4. & $\begin{array}{l}\text { Pembelajaran yang dilakukan guru dapat menarik perhatian } \\
\text { siswa }\end{array}$ & 3 \\
\hline 5. & $\begin{array}{l}\text { Siswa mendengarkan ketika guru memberi penjelasan } \\
\text { tentang pembelajaran role playing }\end{array}$ & 3 \\
\hline 6. & $\begin{array}{l}\text { Siswa memperhatikan ketika guru memberikan contoh dan } \\
\text { pembelajaran role playing }\end{array}$ & 3 \\
\hline
\end{tabular}




\begin{tabular}{clc}
\hline No & \multicolumn{1}{c}{ Aspek yang diobservasi } & Pertemuan I \\
\hline 7. & $\begin{array}{l}\text { Siswa melakukan persiapan dalam pembelajaran nilai-nilai } \\
\text { karakter peduli sosial dengan metode role playing }\end{array}$ & 3 \\
\hline 8. & $\begin{array}{l}\text { Siswa mengikuti instruksi yang diberikan dengan metode } \\
\text { role playing dalam pembelajaran nilai-nilai karakter peduli } \\
\text { sosial }\end{array}$ & 3 \\
\hline 9. & $\begin{array}{l}\text { Siswa melakukan tindakan dramatik dan diskusi yang } \\
\text { diberikan dengan metode role playing dalam pembelajaran } \\
\text { nilai-nilai karakter peduli sosial }\end{array}$ & 3 \\
\hline 10. & $\begin{array}{l}\text { Siswa merasa tertarik dan antusias untuk melakukan } \\
\text { pembelajaran dengan metode role playing }\end{array}$ & 5 \\
\hline 11. & $\begin{array}{l}\text { Siswa tampak senang setelah mengikuti pembelajaran } \\
\text { dengan metode role playing. }\end{array}$ & 5 \\
\hline Jumlah Skor & 39 \\
\hline Skor Maksimal & $70,90 \%$ \\
\hline Persentase rata-rata & 55 \\
\hline
\end{tabular}

Dari hasil observasi di atas di atas bisa dilihat bahwa rata-rata atau persentase yang diperoleh mengenai pembelajaran dengan metode role playing Kelas V SDI Miftahul Huda Plosokandang Kabupaten Tulungagung pada pertemuan I yaitu $70,90 \%$ dalam predikat atau kategori cukup. Hal ini disebabkan metode role playing belum maksimal dalam pelaksanaannya, masih ada siswa yang kurang memahami karakter perannya, sehingga guru mengulang metode role playing pada pertemuan berikutnya.

b. Pertemuan Kedua

1) Persiapan

Persiapan pembelajaran dengan metode role playing yang pertama dilakukan oleh guru adalah melakukan persiapan. Berdasarkan wawancara Berdasarkan wawancara dengan kepala sekolah mengenai persiapan yang dilakukan dalam metode role playing dalam pembelajaran nilai-nilai karakter peduli sosial yaitu guru dan siswa mempersiapkan dialog bermain peran yang akan diperagakan di depan kelas sebagaimana hasil wawancara dengan kepala sekolah yang menyatakan bahwa: "Kepala sekolah mengetahui persiapan yang dilakukan dalam metode role playing dalam pembelajaran nilai-nilai 
karakter peduli sosial yaitu guru dan siswa mempersiapkan dialog bermain peran yang akan diperagakan di depan kelas seperti yang dilakukan pada pertemuan pertama”. (Wawancara: Kusmani, 2/4/2019).

Berdasarkan wawancara dengan guru mengenai persiapan yang dilakukan dalam metode role playing dalam pembelajaran nilai-nilai karakter peduli sosial, menyatakan bahwa: "Persiapan yang dilakukan sama dengan pertemuan pertama yaitu menentukan topik, memilih dan pemberitahuan pada siswa sesuai dengan perannya masing-masing siswa. Dalam pertemuan kedua ini siswa mulai terbiasa dengan kegiatan pembelajaran bermain peran". (Wawancara: Tuminah, 2/4/2019). Data tersebut didukung dengan wawancara yang menyatakan bahwa: "Jika dalam satu pertemuan belum sesuai harapan, guru akan melakukan pertemuan berikutnya dengan metode yang sama, persiapan dilakukan lebih matang, sehingga nanti hasilnya lebih baik". (Wawancara: Sholeh Ridlo, 2/4/2019).

Berdasarkan wawancara dengan siswa mengenai persiapan yang dilakukan dalam metode role playing dalam pembelajaran nilai-nilai karakter peduli sosial menyatakan bahwa: "Saya dikasih teks dialog permainan peran yang harus dihafalkan di rumah. Pada pertemuan kedua ini saya sudah mulai paham dalam pelaksanaannya, berasa asyik mengikutinya". (Wawancara: Iqbal Ashar Handika, 4/4/2019). Hal ini senada juga diungkapkan oleh siswa yang menyatakan bahwa: "Saya diberi oleh ibu guru teks dialog yang harus saya hapalkan dulu dirumah untuk ditampilkan pada waktu masuk sekolah, saya harus menghafalkan lagi agar bisa berperan nantinya. Asyik juga sih ternyata, senang dan lebih paham lagi mengenai tema yang dimainkan". (Wawancara: Safira, 4/4/2019).

Dari hasil wawancara tersebut dapat diketahui guru kelas dan siswa mengungkapkan bahwa persiapan yang dilakukan dalam metode role playing dalam pembelajaran nilai-nilai karakter peduli sosial yaitu guru dan siswa dalam pertemuan kedua ini masih harus mempersiapkan 
dialog bermain peran yang akan diperagakan di depan kelas, sehingga dapat berperan dengan baik sesuai karakter dalam teks.

2) Tindakan dramatik dan diskusi

Tindakan dramatik dilakukan siswa dengan memerankan tokohtokoh sesuai dengan bagiannya masing-masing dengan dampingan guru gelas. Siswa melaksanakan perannya dengan senang dan gembira. Tindakan diskusi dilakukan setelah pemain selesai memainkan peran secara keseluruhan, mereka kembali ke tempat duduk masing-masing. Selanjutnya siswa yang tidak memerankan tokoh dalam kejadian ini bertugas sebagai pengamat. Mereka mendiskusikan jalannya permainan peran dari awal hingga akhir. Dan yang terpenting, siswa bisa memahami inti dari permainan peran tersebut. Sehingga mereka tidak akan kesulitan memahami pelajaran.

Berdasarkan wawancara dengan kepala sekolah mengetahui mengenai tindakan dramatik dan diskusi yang diberikan dalam metode role playing dalam pembelajaran nilai-nilai karakter peduli sosial, hal itu dilakukan untuk mendemonstrasikan peran yang sedang dimainkan oleh siswa sebagaimana hasil wawancara dengan kepala sekolah yang menyatakan bahwa: "Kepala sekolah mengetahui tindakan dramatik dan diskusi yang diberikan dalam metode role playing dalam pembelajaran nilai-nilai karakter peduli sosial, hal itu dilakukan untuk mendemonstrasikan peran yang sedang dimainkan oleh siswa. Kegiatan pembelajaran ya diawal siswa harus terbiasa dulu, nanti pasti lama-lama akan terbiasa juga, seperti yang dilakukan pada pertemuan pertama”. (Wawancara: Kusmani, 4/4/2019).

Berdasarkan wawancara dengan guru mengenai tindakan dramatik dan diskusi yang diberikan dalam metode role playing dalam pembelajaran nilai-nilai karakter peduli sosial menyatakan bahwa: "Pelaksanaan bermain peran dilakukan sesuai yang direncanakan. dipertemuan kedua ini siswa sudah mulai berperan dengan baik dan mulai paham dengan karakter peran yang dimainkannya masingmasing". (Wawancara: Tuminah, 4/4/ 2019). Data tersebut didukung 
dengan wawancara yang menyatakan bahwa: "Pelaksanaan bermain peran dilaksanakan sesuai dengan perencanaan. Siswa sudah terlihat memerankan permainan perannya dengan baik, sehingga menjiwai karakter masing-masing perannnya, siswa senang”. (Wawancara: Sholeh Ridlo, 2/4/ 2019).

Berdasarkan wawancara dengan siswa mengenai tindakan dramatik dan diskusi yang diberikan dalam metode role playing dalam pembelajaran nilai-nilai karakter peduli sosial menyatakan bahwa: "Kegiatan bermain peran kedua sungguh menyenangkan. Aku bisa memerankannya, lumayanlah walaupun ada teks yang lupa tadi, tapi aku sangat suka”. (Wawancara: Iqbal Ashar Handika, 29/3/2019). Hal senada juga diungkapkan oleh siswa yang menyatakan bahwa: "Saya sangat senang baik dipertemuan 1 dan 2 ini dalam bermain peran, karena saya selalu dapat menjiwai peran tersebut dan menggugah hati saya untuk lebih peduli terhadap lingkungan saya dan dapat penilaian dari guru dengan sangat menyenangkan". (Wawancara: Safira, 29/3/2019).

Dari hasil wawancara tersebut dapat diketahui kepala sekolah, guru kelas dan siswa mengungkapkan bahwa tindakan dramatik dan diskusi yang diberikan dalam metode role playing dalam pembelajaran nilai-nilai karakter peduli sosial, hal itu dilakukan untuk mendemonstrasikan peran yang sedang dimainkan oleh siswa, walaupun masih ada siswa yang lupa teksnya, namun tetap berjalan sangat menyenangkan.

3) Evaluasi bermain peran

Evaluasi bermain peran dilakukan guru untuk memberikan komentar dan penghargaan atas terlaksanannya kegiatan pembelajaran bermain peran. Berdasarkan wawancara dengan kepala sekolah mengetahui mengenai evaluasi bermain peran yang diberikan dalam metode role playing. Sebagaimana hasil wawancara dengan kepala sekolah yang menyatakan bahwa: "Kepala sekolah mengetahui evaluasi bermain peran yang diberikan dalam metode role playing dalam pembelajaran nilai-nilai karakter peduli sosial dengan melihat 
keseriusan siswa dalam berakting dan semangat belajarnya menjadi lebih baik serta yang terpenting siswa lebih peduli dengan lingkungan sekitar. Dalam pelaksanaan pembelajaran pertemuan pertama masih kurang baik, siswa belum begitu menguasai perannya seperti yang dilakukan pada pertemuan pertama". (Wawancara: Kusmani, 8/4/2019).

Berdasarkan wawancara dengan guru mengenai evaluasi bermain peran yang diberikan dalam metode role playing dalam pembelajaran nilai-nilai karakter peduli sosial, menyatakan bahwa: "Seperti halnya dengan pertemuan pertama, guru tetap memberikan evaluasi setelah permainan peran dilaksanakan. Pembelajaran dengan metode role playing membutuhkan pembiasaan, pada pertemuan kedua ini sudah lumayan bagus menguasai karakter perannya, walaupun tadi ada siswa yang lupa teksnya". (Wawancara: Tuminah, 8/4/ 2019). Data tersebut didukung dengan wawancara yang menyatakan bahwa: "Setelah pelaksanaan bermain peran dilaksanakan guru melakukan evaluasi, yang mana biasanya guru mengoreksi dan memberikan komentar serta penghargaan pada permainan siswa". (Wawancara: Sholeh Ridlo, 2/4/ 2019).

Berdasarkan wawancara dengan siswa mengenai evaluasi bermain peran yang diberikan dengan metode role playing dalam pembelajaran nilai-nilai karakter peduli sosial, menyatakan bahwa: "Setelah bermain peran, teman-teman pengamat diberi pertanyaan oleh ibu guru dan setelah itu guru memberikan penilaian pada setiap permainan peran, sehingga semangat lagi untuk belajar". (Wawancara: Iqbal Ashar Handika, 8/4/2019). Hal ini senada juga diungkapkan oleh siswa yang menyatakan bahwa: "Seperti pertemuan pertama, teman-teman yang menjadi pengamat diberi pertanyaan yang berkaitan dengan keberhasilan saya dan teman-teman dalam bermain peran”. (Wawancara:Safira, 8/4/2019).

Dari hasil wawancara tersebut dapat diketahui guru kelas mengungkapkan bahwa evaluasi bermain peran yang diberikan dalam metode role playing dalam pembelajaran nilai-nilai karakter peduli 
sosial dengan melihat keseriusan siswa dalam berakting dan semangat belajarnya menjadi lebih baik serta yang terpenting siswa lebih peduli dengan lingkungan sekitar. Pembelajaran dengan metode role playing yang mengembangkan karakter peduli sosial siswa-siswa Kelas V SDI Miftahul Huda Plosokandang Kabupaten Tulungagung dapat berdasarkan hasil observasi kegiatan pembelajaran. Data hasil observasi kegiatan pembelajaran disajikan dalam tabel sebagai berikut:

Tabel 4. Observasi Kegiatan Pembelajaran 2

\begin{tabular}{|c|c|c|}
\hline No & Aspek yang diobservasi & $\begin{array}{l}\text { Pertemuan } \\
\quad \text { II }\end{array}$ \\
\hline 1. & $\begin{array}{l}\text { Cara penyampaian dan penjelasan guru tentang } \\
\text { pembelajaran role playing dapat diterima oleh siswa }\end{array}$ & 4 \\
\hline 2. & $\begin{array}{l}\text { Penggunaan alat peraga digunakan guru dengan baik } \\
\text { dalam pembelajaran }\end{array}$ & 4 \\
\hline 3. & $\begin{array}{l}\text { Guru dapat mengajak siswa untuk aktif mengikuti } \\
\text { pembelajaran role playing }\end{array}$ & 4 \\
\hline 4. & $\begin{array}{l}\text { Pembelajaran yang dilakukan guru dapat menarik } \\
\text { perhatian siswa }\end{array}$ & 3 \\
\hline 5. & $\begin{array}{l}\text { Siswa mendengarkan ketika guru memberi penjelasan } \\
\text { tentang pembelajaran role playing }\end{array}$ & 3 \\
\hline 6. & $\begin{array}{l}\text { Siswa memperhatikan ketika guru memberikan contoh dan } \\
\text { pembelajaran role playing }\end{array}$ & 4 \\
\hline 7. & $\begin{array}{l}\text { Siswa melakukan persiapan dalam pembelajaran nilai-nilai } \\
\text { karakter peduli sosial dengan metode role playing }\end{array}$ & 4 \\
\hline 8. & $\begin{array}{l}\text { Siswa mengikuti instruksi yang diberikan dengan metode } \\
\text { role playing dalam pembelajaran nilai-nilai karakter peduli } \\
\text { sosial }\end{array}$ & 4 \\
\hline & $\begin{array}{l}\text { Siswa melakukan tindakan dramatik dan diskusi yang } \\
\text { diberikan dengan metode role playing dalam pembelajaran } \\
\text { nilai-nilai karakter peduli sosial }\end{array}$ & 4 \\
\hline 10. & $\begin{array}{l}\text { Siswa merasa tertarik dan antusias untuk melakukan } \\
\text { pembelajaran dengan metode role playing }\end{array}$ & 5 \\
\hline 11. & $\begin{array}{l}\text { Siswa tampak senang setelah mengikuti pembelajaran } \\
\text { dengan metode role playing. }\end{array}$ & 5 \\
\hline \multicolumn{2}{|c|}{ Jumlah Skor } & 44 \\
\hline \multicolumn{2}{|c|}{ Skor Maksimal } & 55 \\
\hline \multicolumn{2}{|c|}{ Persentase rata-rata } & $80,00 \%$ \\
\hline
\end{tabular}

Dari hasil observasi di atas bisa dilihat bahwa rata-rata atau presentase yang diperoleh mengenai pembelajaran dengan metode role playing Kelas V SDI Miftahul Huda Plosokandang Kabupaten 
Tulungagung pada pertemuan I yaitu $80,00 \%$ dalam predikat atau kategori baik. Hal ini disebabkan metode role playing sudah mulai terbiasa dalam pelaksanaannya, masih ada siswa kelompok siswa yang kurang benar dalam meminkan perannya, sehingga guru mengulang metode role playing pada pertemuan berikutnya.

c. Pertemuan Ketiga

1) Persiapan

Persiapan dalam kegiatan bermain peran dilakukan dengan semangat dan siswa bersungguh-sungguh untuk bisa menampilkan perannya dengan baik. Persiapan yang dilakukan dalam metode role playing dalam pembelajaran nilai-nilai karakter peduli sosial yaitu guru dan siswa mempersiapkan dialog bermain peran yang akan diperagakan di depan kelas. Berdasarkan wawancara dengan kepala sebagaimana hasil wawancara dengan kepala sekolah yang menyatakan bahwa: "Kepala sekolah mengetahui persiapan yang dilakukan. Persiapan dalam kegiatan bermain peran dilakukan dengan semangat dan siswa bersungguh-sungguh untuk bisa menampilkan perannya dengan baik. Persiapan yang dilakukan dalam metode role playing dalam pembelajaran nilai-nilai karakter peduli sosial yaitu guru dan siswa mempersiapkan dialog bermain peran yang akan diperagakan di depan kelas”. (Wawancara: Kusmani, 2/4/2019).

Berdasarkan wawancara dengan guru mengenai persiapan yang dilakukan dalam metode role playing dalam pembelajaran nilai-nilai karakter peduli sosial, menyatakan bahwa: Persiapan terlaksana dengan baik. Terlihat saat bermain peran, anak-anak hafal teksnya. Dalam pertemuan ketiga ini siswa sudah terbiasa dengan kegiatan pembelajaran bermain peran. (Wawancara: Tuminah, 2/4/ 2019). Data tersebut didukung dengan wawancara yang menyatakan bahwa: "Pada tahap persiapan ini harus dipersiapkan dengan matang, agar pelaksanaannya nanti tidak mengecewakan. Dan hasilnya siswa sudah bisa memerankan perannya dengan baik dan bisa bekerjasama dengan teman". (Wawancara: Sholeh Ridlo, 2/4/ 2019). 
Berdasarkan wawancara dengan siswa mengenai persiapan yang dilakukan dalam metode role playing dalam pembelajaran nilai-nilai karakter peduli sosial menyatakan bahwa: "Saya hafalin lagi teks yang diberikan guru hingga hafal, saya hanya melakukan sedikit kesalahan, dan mendapatkan penilaian yang baik dari guru". (Wawancara: Iqbal Ashar Handika, 4/4/2019). Hal ini senada juga diungkapkan oleh siswa yang menyatakan bahwa: "Saya lagi-lagi diberi oleh ibu guru teks dialog yang harus saya hapalkan dulu dirumah untuk bermain peran di kelas minggu depan. Saya hafalin dengan baik, dan memperhatikan karakter yang harus aku mainkan nantinya”. (Wawancara: Safira, 4/4/2019). Dari hasil wawancara tersebut dapat diketahui kepala sekolah, guru kelas dan siswa mengungkapkan bahwa persiapan yang dilakukan dalam metode role playing dalam pembelajaran nilai-nilai karakter peduli sosial yaitu guru dan siswa mempersiapkan dialog bermain peran yang akan diperagakan di depan kelas.

2) Tindakan dramatik dan diskusi

Tindakan dramatik dan diskusi dilakukan guru kelas dan siswa yang diberikan dalam metode role playing dalam pembelajaran nilai-nilai karakter peduli sosial, hal itu dilakukan untuk mendemonstrasikan peran yang sedang dimainkan oleh siswa yang nantinya akan didiskusikan bersama setelah permainan peran selesai. Berdasarkan wawancara dengan kepala sekolah mengetahui tindakan dramatik dan diskusi dilakukan guru kelas dan siswa yang diberikan dalam metode role playing dalam pembelajaran nilai-nilai karakter peduli sosial, hal itu dilakukan untuk mendemonstrasikan peran yang sedang dimainkan oleh siswa yang nantinya akan didiskusikan bersama setelah permainan peran selesai sebagaimana hasil wawancara dengan kepala sekolah yang menyatakan bahwa: "Kepala sekolah mengetahui tindakan dramatik dan diskusi dilakukan guru kelas dan siswa yang diberikan dalam metode role playing dalam pembelajaran nilai-nilai karakter peduli sosial, hal itu dilakukan untuk mendemonstrasikan peran yang sedang dimainkan 
oleh siswa yang nantinya akan didiskusikan bersama setelah permainan peran selesai”. (Wawancara: Kusmani, 4/4/2019).

Berdasarkan wawancara dengan guru mengenai tindakan dramatik dan diskusi yang diberikan dalam metode role playing dalam pembelajaran nilai-nilai karakter peduli sosial menyatakan bahwa: "Pelaksanaan bermain sudah sesuai dengan harapan, siswa bisa menguasai perannya dan hafal teksnya, mereka terlihat sangat senang dan bagus permainan perannya”. (Wawancara: Tuminah, 4/4/ 2019). Data tersebut didukung dengan wawancara yang menyatakan bahwa: "Permainan peran dilaksanakan sesuai dengan perencanaan yang telah dibuat pada tahap persiapan, siswa mulai memainkan peran dan pastinya terlihat menyenangkan telah sesuai harapan". (Wawancara: Sholeh Ridlo, 2/4/ 2019).

Berdasarkan wawancara dengan siswa mengenai tindakan dramatik dan diskusi yang diberikan dalam metode role playing dalam pembelajaran nilai-nilai karakter peduli sosial menyatakan bahwa: "Bermain peran lagi sungguh menyenangkan. Membuat saya lebih ingin banyak membantu jika ada yang membutuhkan dan senang mengikuti pembelajaran". (Wawancara: Iqbal Ashar Handika, 29/3/2019). Hal senada juga diungkapkan oleh siswa yang menyatakan bahwa: "Saya sangat senang dalam bermain peran, karena dapat menjiwai peran tersebut dan menggugah hati saya untuk lebih peduli terhadap lingkungan saya". (Wawancara: Safira, 29/3/2019). Dari hasil wawancara tersebut dapat diketahui guru kelas dan siswa mengungkapkan bahwa tindakan dramatik dan diskusi yang diberikan dalam metode role playing dalam pembelajaran nilai-nilai karakter peduli sosial, hal itu dilakukan untuk mendemonstrasikan peran yang sedang dimainkan oleh siswa.

3) Evaluasi bermain peran

Berdasarkan wawancara dengan kepala sekolah mengetahui mengenai evaluasi bermain peran yang diberikan dalam metode role playing dalam pembelajaran nilai-nilai karakter peduli sosial dengan 
melihat keseriusan siswa dalam berakting dan semangat belajarnya menjadi lebih baik serta yang terpenting siswa lebih peduli dengan lingkungan sekitar sebagaimana hasil wawancara dengan kepala sekolah yang menyatakan bahwa: "Kepala sekolah mengetahui evaluasi bermain peran yang diberikan dalam metode role playing dalam pembelajaran nilai-nilai karakter peduli sosial dengan melihat keseriusan siswa dalam berakting dan semangat belajarnya menjadi lebih baik serta yang terpenting siswa lebih peduli dengan lingkungan sekitar. Dalam pelaksanaan pembelajaran pertemuan ketiga ini siswa mengalami perkembangan yaitu siswa sudah menguasai perannya. (Wawancara: Kusmani, 8/4/2019).

Berdasarkan wawancara dengan guru mengenai evaluasi bermain peran yang diberikan dalam metode role playing dalam pembelajaran nilai-nilai karakter peduli sosial, menyatakan bahwa: "Guru memberikan penilaian dan memberikan keputusan berhasilnya kegiatan permainan peran yang telah berlangsung. Pembelajaran dengan metode role playing sudah terlaksana dengan baik siswa sudah menguasai karakter perannya". (Wawancara: Tuminah, 8/4/ 2019). Data tersebut didukung dengan wawancara yang menyatakan bahwa: "Pada pertemuan ketiga ini setelah diadakan pelaksanaan bermain peran ada penilaian yang dilakukan oleh guru, yang mana guru memberikan arahan dan perbaikan yang harus dilakukan oleh siswa. Pelaksanaannya sudah sesuai dengan harapan, guru memberikan penghargaan melalui ucapan". (Wawancara: Sholeh Ridlo, 8/4/2019).

Berdasarkan wawancara dengan siswa mengenai evaluasi bermain peran yang diberikan dengan metode role playing dalam pembelajaran nilai-nilai karakter peduli sosial, menyatakan bahwa: "Setelah bermain peran, teman-teman pengamat diberi pertanyaan oleh ibu guru dan ibu guru juga memberikan komentar yang menyenangkan”. (Wawancara: Iqbal Ashar Handika, 8/4/2019). Hal senada juga diungkapkan oleh siswa yang menyatakan bahwa: "Seperti pertemuan sebelumnya teman-teman yang menjadi pengamat diberi pertanyaan 
yang berkaitan dengan keberhasilan saya dan teman-teman dalam bermain peran”. (Wawancara:Safira, 8/4/2019).

Dari hasil wawancara tersebut dapat diketahui guru kelas dan siswa mengungkapkan bahwa evaluasi bermain peran yang diberikan dalam metode role playing dalam pembelajaran nilai-nilai karakter peduli sosial dengan melihat keseriusan siswa dalam berakting dan semangat belajarnya menjadi lebih baik serta yang terpenting siswa lebih peduli dengan lingkungan sekitar. Pembelajaran dengan metode role playing yang mengembangkan karakter peduli sosial siswa-siswa Kelas V SDI Miftahul Huda Plosokandang Kabupaten Tulungagung dapat berdasarkan hasil observasi kegiatan pembelajaran. Data hasil observasi kegiatan pembelajaran disajikan dalam tabel sebagai berikut:

Tabel 5. Observasi Kegiatan Pembelajaran 3

\begin{tabular}{|c|l|c|}
\hline No & \multicolumn{1}{|c|}{ Aspek yang diobservasi } & $\begin{array}{c}\text { Pertemuan } \\
\text { III }\end{array}$ \\
\hline 1. & $\begin{array}{l}\text { Cara penyampaian dan penjelasan guru tentang } \\
\text { pembelajaran role playing dapat diterima oleh siswa }\end{array}$ & 4 \\
\hline 2. & $\begin{array}{l}\text { Penggunaan alat peraga digunakan guru dengan baik dalam } \\
\text { pembelajaran }\end{array}$ & 5 \\
\hline 3. & $\begin{array}{l}\text { Guru dapat mengajak siswa untuk aktif mengikuti } \\
\text { pembelajaran role playing }\end{array}$ & 5 \\
\hline 4. & $\begin{array}{l}\text { Pembelajaran yang dilakukan guru dapat menarik perhatian } \\
\text { siswa }\end{array}$ & 5 \\
\hline 5. & $\begin{array}{l}\text { Siswa mendengarkan ketika guru memberi penjelasan } \\
\text { tentang pembelajaran role playing }\end{array}$ & 4 \\
\hline 6. & $\begin{array}{l}\text { Siswa memperhatikan ketika guru memberikan contoh dan } \\
\text { pembelajaran role playing }\end{array}$ & 5 \\
\hline 7. & $\begin{array}{l}\text { Siswa melakukan persiapan dalam pembelajaran nilai-nilai } \\
\text { karakter peduli sosial dengan metode role playing }\end{array}$ & 5 \\
\hline 8. & $\begin{array}{l}\text { Siswa mengikuti instruksi yang diberikan dengan metode } \\
\text { role playing dalam pembelajaran nilai-nilai karakter peduli } \\
\text { sosial }\end{array}$ & 5 \\
\hline 9. & $\begin{array}{l}\text { Siswa melakukan tindakan dramatik dan diskusi yang } \\
\text { diberikan dengan metode role playing dalam pembelajaran } \\
\text { nilai-nilai karakter peduli sosial }\end{array}$ & $\begin{array}{l}\text { Jumlah Skor } \\
\text { pembelajaran dengan metode role playing }\end{array}$ \\
\hline 10. & $\begin{array}{l}\text { Siswa merasa tertarik dan antusias untuk melakukan } \\
\text { dengan metode role playing. }\end{array}$ & 5 \\
\hline 11. & \begin{tabular}{l} 
Siswa tampak senang setelah mengikuti pembelajaran \\
\hline
\end{tabular} & 5 \\
\hline
\end{tabular}

Analisis Nilai Karakter Peduli Sosial Melalui Metode Role Playing... 


\begin{tabular}{|c|c|c|}
\hline No & Aspek yang diobservasi & $\begin{array}{c}\text { Pertemuan } \\
\text { III }\end{array}$ \\
\hline \multicolumn{2}{|c|}{ Skor Maksimal } & 55 \\
\hline Persentase rata-rata & $94,54 \%$ \\
\hline
\end{tabular}

Dari hasil observasi di atas bisa dilihat bahwa rata-rata atau presentase yang diperoleh mengenai pembelajaran dengan metode role playing Kelas V SDI Miftahul Huda Plosokandang Kabupaten Tulungagung pada pertemuan III yaitu $94,54 \%$ dalam predikat atau kategori sangat baik. Hal ini disebabkan penggunaan metode role playing sudah benar-benar maksimal dilaksanakan, sehingga tidak dibutuhkan pengulangan metode role playing.

\section{Pembahasan}

1. Nilai-nilai karakter peduli sosial siswa saat atau setelah mengikuti pembelajaran dengan metode role playing

Nilai-nilai karakter peduli sosial melalui metode role playing dalam proses pembelajaran di Kelas V SDI Miftahul Huda Plosokandang Kabupaten Tulungagung dapat diketahui berdasarkan perolehan skor rata-rata sebesar 4,121 dengan persentase 82,42 atau dalam kategori Baik. Hal ini mencerminkan bahwa nilai-nilai karakter peduli sosial siswa saat mengikuti pembelajaran dengan metode role playing Kelas V SDI Miftahul Huda Plosokandang Kabupaten Tulungagung kategori baik. Sedangkan untuk nilai-nilai karakter peduli sosial melalui metode role playing setelah pembelajaran di Kelas V SDI Miftahul Huda Plosokandang Kabupaten Tulungagung yang diketahui dari teman siswa dapat diketahui berdasarkan perolehan skor rata-rata sebesar 4,125 dengan persentase 82,5 atau dalam kategori Baik. Hal ini mencerminkan bahwa nilai-nilai karakter peduli sosial siswa setelah mengikuti pembelajaran dengan metode role playing di Kelas V SDI Miftahul Huda Plosokandang Kabupaten Tulungagung kategori Baik. Dengan demikian siswa dengan temannya memiliki perilaku yang lemah lembut, sopan, mengucapkan salam ketika masuk kelas dan bertegur sapa dengan teman, berbicara santun, mengajak berjabat tangan, menyapa dan tersenyum saat bertemu dengan orang 
lain, menghargai orang lain dengan tidak memaksakan kehendaknya, sehingga tercipta lingkungan yang mempunyai kepedulian sosial yang baik.

Hasil penelitian ini juga di dukung oleh peneliti terdahulu yang dilakukan oleh Agung (2018) yang hasil penelitiannya menunjukkan bahwa adanya peningkatan nilai-nilai karakter perilaku sosial siswa setelah mengikuti pembelajaran dengan model pendidikan karakter melalui bermain peran. Hasil penelitian ini menurut Listyarti (2012: 7), peduli sosial merupakan suatu tindakan atau sikap untuk membantu orang lain yang memerlukan bantuan. Yaumi (2014: 77) menjelaskan bahwa kepedulian sosial ialah suatu bentuk kesadaran manusia sebagai makhluk sosial yang tidak memungkinkan untuk hidup sendirian. Dengan demikian, peduli sosial ialah suatu tindakan yang dilakukan dengan sengaja kepada orang lain yang membutuhkan.

Hasil penelitian ini juga didukung oleh Majid (2015: 25) yang menyatakan bahwa nilai merupakan suatu norma yang telah ditetapkan yang telah menyatu pada diri siswa. Nilai baik maupun buruk serta pengaturan tindakan siswa harus ditetapkan dalam diri siswa. Pendapat tersebut diperkuat menurut Yanti (2016: 2) yang menganggap bahwa nilai (value) sebagai norma yang baik, karena akan dapat menunjukkan jalan dalam melaksanakan tugas dalam kehidupan misalnya nilai: kejujuran, kesederhanaan dan lain sebagainya. Kegiatan pembelajaran yang menyenangkan di kelas sangat dibutuhkan oleh siswa. Dengan metode pembelajaran role playing, siswa banyak belajar tentang berbagai peran terkait kepedulian sosial. Penguatan karakter peduli sosial melalui metode role playing ditujukan untuk membentuk jiwa kedermawanan dan rasa kepedulian sosial yang tinggi agar dapat diterapkan dan ditanamkan dalam kehidupan keseharian siswa.

2. Pembelajaran dengan metode role playing yang mengembangkan karakter peduli sosial siswa-siswa Kelas V SDI Miftahul Huda Plosokandang Kabupaten Tulungagung

Pembelajaran dengan metode role playing yang mengembangkan karakter peduli sosial siswa-siswa Kelas V SDI Miftahul Huda Plosokandang Kabupaten Tulungagung dilakukan dengan 3 pertemuan. Berdasarkan hasil observasi kegiatan pembelajaran diperoleh dari rata-rata atau persentase yang diperoleh 
pada pertemuan I yaitu 70,90\% dalam predikat atau kategori cukup. Sedangkan pertemuan II yaitu $80,00 \%$ dalam predikat atau kategori baik. Selanjutnya pertemuan III yaitu yaitu 94,54\% dalam predikat atau kategori sangat baik.

Hasil penelitian ini sesuai menurut Role playing sebagai suatu pembelajaran yang bertujuan untuk membantu siswa menemukan diri (jati diri) didunia sosial dan memecahkan dilema dengan bantuan kelompok (Hamzah, 2009: 26). Melalui pembelajaran yang lebih menggunakan teknik bermain peran, siswa dapat belajar memaknai konsep peran, siswa mempunyai kesadaran mengenai peran-peran yang berbeda dan siswa mampu menggunakan olah pikirannya untuk berperilaku dengan orang lain (Haryanti, 2014). Pendapat tersebut diperkuat menurut Hamdani (2011: 87). pembelajaran dengan role playing adalah suatu teknik agar siswa lebih menguasai materi pelajaran yang dilakukan dengan lebih mengembangkan imajinasi dan penghayatan siswa. Perkembangan imajinasi dan penghayatan pada siswa dilakukan dengan bermain peran sebagai tokoh yang diperankan oleh siswa. Role playing merupakan suatu metode yang lebih banyak interaksi siswa baik dengan siswa lainnya atau dengan situasi sosial yang ada di lingkungan sekitar. Siswa bertindak memerankan tokoh yang sesuai menjadi lakonnya. Siswa berinteraksi untuk memerankan peran secara terbuka. Dalam pelaksanaan metode ini seorang guru dituntut untuk mencermati apa yang perlu dibenahi dari perilaku yang diperankan oleh siswa (Yamin, 2012: 87).

Hasil penelitian ini juga didukung oleh pendapat Miftahul Huda (2013:115) menjelaskan esensi role playing adalah keterlibatan partisipan dan peneliti dalam situasi permasalahan dan adanya keinginan untuk memunculkan resolusi damai serta memahami apa yang dihasilkan dari keterlibatan langsung ini. Role playing berfungsi untuk mengeksplorasi perasaan siswa, mentranfer dan mewujudkan pandangan mengenai perilaku, nilai dan persepsi siswa, mengembangkan skill pemecahan masalah dan tingkah laku, dan mengekplorasi materi pelajaran dengan cara yang berbeda.

Penggunaan metode role playing dalam meningkatkan karakter peduli sosial juga didukung oleh Samani dan Hariyanto (2012: 157) bermain drama dilakukan dengan tujuan agar siswa memperoleh keterampilan tertentu dan 
siswa memperoleh pemahaman tentang suatu konsep atau prinsip serta bertujuan untuk memecahkan suatu masalah yang relevan dengan pendidikan karakter. Hasil penelitian ini didukung oleh penelitian terdahulu yang dilakukan oleh Kiromim Baroroh (2011) yang hasil penelitiannya menunjukan bahwa terjadinya peningkatan nilai-nilai karakter siswa yang dapat dilihat dari indikator disiplin, kerja keras, kreatif dan kemampuan komunikasi antar siswa.

\section{Simpulan}

Berdasarkan hasil penelitian dapat disimpulkan sebagai berikut:

1. Nilai-nilai karakter peduli sosial yang muncul saat atau setelah pembelajaran dengan metode role playing di kelas V SDI Miftahul Huda Plosokandang Kabupaten Tulungagung adalah sebagai berikut: nilai-nilai karakter peduli sosial siswa saat mengikuti pembelajaran dengan metode role playing dapat dilihat nilai rata-rata sebesar 4,121 dengan persentase 82,42 dalam kategori baik. Artinya nilai-nilai karakter peduli sosial dapat dikategorikan baik. Sedangkan nilai-nilai karakter peduli sosial siswa setelah mengikuti pembelajaran dengan metode role playing yang mana angket diisi oleh teman dari siswa dilihat rata-rata sebesar 4,125 dengan persentase 82,5 atau dalam kategori baik. Artinya nilai-nilai karakter peduli sosial dapat dikategorikan baik.

2. Pembelajaran dengan metode role playing yang mengembangkan karakter peduli sosial siswa-siswa Kelas V SDI Miftahul Huda Plosokandang Kabupaten Tulungagung dilakukan dengan 3 pertemuan. Berdasarkan hasil observasi kegiatan pembelajaran diperoleh dari rata-rata atau persentase yang diperoleh pada pertemuan I yaitu 70,90\% dalam predikat atau kategori cukup. Sedangkan pertemuan II yaitu $80,00 \%$ dalam predikat atau kategori Baik. Selanjutnya pertemuan III yaitu yaitu 94,54\% dalam predikat atau kategori Sangat Baik.

\section{DAFTAR RUJUKAN}

Agung, P. (2018). Pengembangan Model Pendidikan Karakter Peduli Sosial Melalui Metode Bermain Peran di TK Tunas Mekar Indonesia Bandar Lampung, Vol 1, No 02 (2018) 
Baroroh. Kiromim. (2011). Upaya Meningkatkan Nilai-Nilai Karakter Peserta Didik Melalui Penerapan Metode Role Playing. Jurnal Ekonomi \& Pendidikan. Volume 8 Nomor 2, 149-163

Creswell, John W. (2015). Penelitian Kualitatif \& Desain Riset. Yogyakarta: Pustaka Pelajar.

Hamdani. (2011). Strategi Belajar Mengajar. Bandung : Pustaka Setia

Hamzah. (2009). Strategi Belajar Mengajar. Bandung : Pustaka Setia

Haryanti, Nik (2014), Ilmu pendidikan Islam, Malang: Gunung Samudera

Herdani. (2010). Strategi Belajar Mengajar. Bandung: Pustaka Setia

Huda, M. (2013). Model-model Pengajaran dan Pembelajaran. Yogyakarta: Pustaka Pelajar.

Listyarti, Retno. (2012) Pendidikan Karakter dalam Metode Aktif, Inovatif dan Kreatif, Jakarta: Esensi,

Majid, A. (2015).Strategi Pembelajaran. Bandung: PT Remaja Rosdakarya.

Moleong, L.J. (2012). Metodologi Penelitian Kualitatif. Bandung: Remaja Rosdakarya.

Samani \& Heriyanto. (2012). Konsep dan Model Pendidikan Karakter. Bandung: PT Remaja Rosdakarya

Samani, Muchlas dan Hariyanto (2012), Pendidikan Karakter, Bandung: PT Remaja Rosdakarya

Samani, Muchlas dan Hariyanto, (2013) Konsep dan Model Pendidikan Karakter, Bandung: PT. Remaja Rosdakarya Offset

Samani. (2011). Konsep dan Model Pendidikan Karakter. Bandung: PT Remaja Rosdakarya

Sugiono. (2010). Metode Penelitian Kuantitatif Kualitatif dan R\&D. Bandung: Alfabeta.

Sugiyono. (2011) Metode Penelitian Kuantitatif Kualitatif dan R\&D. Bandung: Alfabeta.

Sugiyono. (2012) Metode Penelitian Kuantitatif Kualitatif dan R\&D. Bandung: Alfabeta.

Yamin. (2012). Strategi dan Metode dalam Model Pembelajaran. Jakarta: Referensi (GP Press Group). 
Yanti, N., Adawiah, R., \& Matnuh, H. (2016). Pelaksanaan Kegiatan Extrakurikuler dalam Rangka Pengembangan Nilai-Nilai Karakter Siswa untuk menjaadi warga yang Baik di SMA KORPRI Banjarmasin.Jurnal Pendidikan Kewarganegaraan.2 (11): 963-970.

Yaumi, Muhammad. (2014) Pendidikan Karakter : Landasan, Pilar dan Implementasi, Jakarta: Kencana,

Yaumi, Muhammad. 2014. Pendidikan Karakter: Landasan, Pilar dan Implementasi, Jakarta: Prenada Media Group 